\title{
Nutrient availability at different altitudes in a tropical montane forest in Ecuador
}

\author{
Nathalie Soethe*, ${ }^{*}$, Johannes Lehmann $\dagger$ and Christof Engels* \\ * Department of Plant Nutrition and Fertilization, Humboldt University of Berlin, Albrecht Thaer Weg 4, 14195 Berlin, Germany \\ $\dagger$ Department of Crop and Soil Sciences, Cornell University, USA \\ (Accepted 21 March 2008)
}

\begin{abstract}
We measured macronutrient concentrations in soils and leaves of trees, shrubs and herbs at 1900, 2400 and $3000 \mathrm{~m}$ in an Ecuadorian tropical montane forest. Foliar N, P, S and K concentrations in trees were highest at $1900 \mathrm{~m}$ $\left(21.7,2.2,1.9\right.$ and $\left.10.0 \mathrm{mg} \mathrm{g}^{-1}\right)$. At 2400 and $3000 \mathrm{~m}$, foliar concentrations of N, P, S and K were similar to nutrient concentrations in tropical trees with apparent nutrient deficiency, as presented in literature. Unlike foliar nutrient concentrations, the amounts of plant-available nutrients in mineral soil were not affected by altitude or increased significantly with increasing altitude. High C:N ratios $(25: 1$ at $2400 \mathrm{~m}$ and 34:1 at $3000 \mathrm{~m})$ and C:P ratios (605:1 at $2400 \mathrm{~m}$ and $620: 1$ at $3000 \mathrm{~m}$ ) in the soil organic layer suggested slow mineralization of plant litter and thus, a low availability of $\mathrm{N}$ and $\mathrm{P}$ at high altitudes. Foliar N:P ratios were significantly higher at $2400 \mathrm{~m}(11.3: 1)$ than at $3000 \mathrm{~m}$ (8.3:1), indicating that at high altitudes, N supply was more critical than P supply. In conclusion, the access of plants to several nutrients, most likely N, P, S and K, decreased markedly with increasing altitude in this tropical montane forest.
\end{abstract}

Key Words: herbs, foliar nutrient analysis, nitrogen, nutritional status, nutrient uptake, phosphorus, root length density, shrubs, trees

\section{INTRODUCTION}

The decrease of above-ground net primary productivity (ANPP) and tree stature with increasing altitude in tropical montane forests is poorly understood. Several explanations for low growth and stature of trees at high altitudes are given in the literature: (1) Low photosynthesis due to persistent cloudiness and thus low radiation input (Bruijnzeel \& Veneklaas 1998) or due to low temperatures (Kitayama \& Aiba 2002); (2) direct impact of low temperatures on growth (Hoch \& Körner 2003); (3) exposure to strong winds (Cordero 1999, Lawton 1982); (4) low nutrient availability due to water-saturated soils, low temperatures and high concentrations of phenolic compounds in soils leading to low decomposition and mineralization rates (Bruijnzeel et al. 1993, Edwards \& Grubb 1977, Tanner et al. 1998); (5) low nutrient uptake capacity due to reduced root respiration or transpiration (Bruijnzeel \& Veneklaas 1998).

\footnotetext{
${ }^{1}$ Corresponding author. Email: Nathalie.Soethe@agrar.hu-berlin.de
}

Correlations between plant growth and nutrient availability have often been observed in tropical montane forests. The exceptional high tree stature in a montane forest stand in Papua New Guinea was attributed to its nutrient-rich soil parent material (Edwards \& Grubb 1977). In Jamaica (Tanner et al. 1990) and Hawaii (Vitousek \& Farrington 1997) trunk diameter growth and leaf production of several native tree species in montane forests were enhanced by addition of nitrogen $(\mathrm{N})$ or phosphorus (P).

Tanner et al. (1998) hypothesized that in tropical montane forests $\mathrm{N}$ limitation is more common than $\mathrm{P}$ limitation whereas tropical lowland forests are usually $\mathrm{P}$ limited. The authors suggested that with regard to N, tropical montane forests appear to function more like forests from higher latitudes than like tropical lowland forests. This suggestion is based on the observation that boreal and temperate forests tend to be strongly $\mathrm{N}$ deficient, whereas tropical forests on old soils (primarily tropical lowland forests) tend to be P deficient (McGroddy et al. 2004, Reich \& Oleksyn 2004, Vitousek et al. 1993).

The nutritional status of plants is governed both by chemical and spatial nutrient availability to plant roots 
(Jungk 2002). Chemical nutrient availability in tropical montane forests may be affected by parent material, weathering intensity, cation exchange capacity, the rates of litter decomposition, or extracellular phosphatase activity (Kitayama \& Aiba 2002, Treseder \& Vitousek 2001, Wilcke et al. in press). Spatial nutrient availability is dependent on the exploitation of soil by roots or mycorrhizal hyphae and the mobility of the respective nutrient in soil. It is likely to be high in the densely rooted organic layers of tropical montane forests (Hertel et al. 2003, Vance \& Nadkarni 1992) and may be further enhanced by high abundance of mycorrhizal fungi (Kottke et al. 2004, Treseder \& Vitousek 2001). At high altitudes of tropical montane forests, spatial availability of nutrients in mineral soil may be decreased due to unfavourable chemical soil properties for root growth (Schrumpf et al. 2001).

Whereas the nutritional status of plants in agricultural ecosystems is comparatively easy to assess, it is often a challenge to determine the factors limiting plant growth in natural forest ecosystems (Stewart 2000, Vitousek \& Farrington 1997). Fertilization experiments are necessary to make definite conclusions about the limitation of ANPP by nutrients, but they are time consuming and therefore often restricted to very few nutrients. In tropical forests such experiments may further be confounded by P-fixation in soil and modest response of slow-growing species to nutrient amendment (Tanner et al. 1998).

Determination of foliar nutrient concentrations allows a rapid examination of many nutrients. However, to assess potential growth limitation by nutrients, critical nutrient concentrations (leaf concentrations that indicate nutrient deficiency or sufficiency) have to be known. For native species of tropical montane forests critical nutrient concentrations are usually not available. A further challenge for assessment of nutrient limitation by foliar analysis in tropical montane forests is their high biodiversity. Neighbouring plant species growing in one stand may differ in the degree of growth limitation by nutrients (Tanner et al. 1990) and foliar nutrient concentrations often vary among individual species (Vitousek et al. 1995). Nevertheless, in several natural forest ecosystems foliar nutrient concentrations have been related to plant nutritional status (Barrick \& Schoettle 1996, McGroddy et al. 2004, Tanner et al. 1998).

In the present study we examined soil nutrient availability and foliar nutrient concentrations at different altitudes of a south Ecuadorian montane forest. The aim was to elucidate factors that may contribute to the reduction of ANPP and tree stature with increasing altitude and therefore, to obtain indications for the nutrient supply to plants. It was hypothesized (1) that adequate nutrient supply is critical at high altitudes and (2) that low nutrient supply at high altitudes is attributed to a slow mineralization rate and shallow root distribution.

\section{STUDY SITES}

Experimental work was carried out at three study sites on the fringes of the Podocarpus National Park on the eastern Andes slope in southern Ecuador. The two lower study sites $\left(1900 \mathrm{~m}\right.$ asl, S $03^{\circ} 58^{\prime} \mathrm{W} 79^{\circ} 04^{\prime}$ and $2400 \mathrm{~m}$ asl, $\mathrm{S} 03^{\circ} 59^{\prime} \mathrm{W} 79^{\circ} 04^{\prime}$ ) were situated in the Reserva San Francisco (RSF), the highest site $\left(3000 \mathrm{~m}, \mathrm{~S} 04^{\circ} 06^{\prime} \mathrm{W}\right.$ $79^{\circ} 10^{\prime}$ ) was located in Cajanuma within the Podocarpus National Park. The sites were all situated on moderate slopes $\left(27-31^{\circ}\right)$.

Maximum tree heights at $1900 \mathrm{~m}$ and $2400 \mathrm{~m}$ were $19 \mathrm{~m}$ and $12 \mathrm{~m}$, respectively (Röderstein et al. 2005). About 250 to 288 tree species from 25 different families occurred in the RSF. Most frequent families were Lauraceae, Rubiaceae and Melastomataceae, and species composition differed markedly between 1900 and $2400 \mathrm{~m}$ (Homeier 2004). The uppermost study site in Cajanuma was located in a typical elfin forest, with a maximum tree height of $9 \mathrm{~m}$ (Röderstein et al. 2005). Notable tree families at this site were Clusiaceae, Cunoniaceae, Aquifoliaceae and Chloranthaceae (Homeier 2004).

Within the study area, above-ground productivity decreased markedly with increasing altitude. As an estimate for annual gross leaf production, Röderstein et al. (2005) reported a decrease of average leaf litter production from $862 \mathrm{~g} \mathrm{~m}^{-2} \mathrm{y}^{-1}$ at $1900 \mathrm{~m}$ to $433 \mathrm{~g} \mathrm{~m}^{-2} \mathrm{y}^{-1}$ at $2400 \mathrm{~m}$ and $263 \mathrm{~g} \mathrm{~m}^{-2} \mathrm{y}^{-1}$ at $3000 \mathrm{~m}$. The relative annual increment in stem cross-sectional area declined from $1.26 \%$ at $1850 \mathrm{~m}$ to $0.63 \%$ at $2450 \mathrm{~m}$ (Homeier 2004).

The soils were developed on metamorphic shale, quartzite or sandstone bedrock and were classified as gleyic Cambisols according to FAO taxonomy at 1900 and $2400 \mathrm{~m}$ and podzols at $3000 \mathrm{~m}$ (S. Iost, pers. comm.). Soils were acid at all altitudes. To a depth of $0.3 \mathrm{~m}$ in mineral soil, $\mathrm{pH}_{\left(\mathrm{CaCl}_{2}\right)}$ ranged between 2.9 and 3.5 at 1900 and $2400 \mathrm{~m}$ and between 2.7 and 2.9 at $3000 \mathrm{~m}$ (Soethe et al. 2006). Following the FAO taxonomy (FAO 1988), the average depth of the upper mineral soil accumulated with humus (Ah) decreased from $0.70 \mathrm{~m}$ at $1900 \mathrm{~m}$ to $0.15 \mathrm{~m}$ at $2400 \mathrm{~m}$ and $0.20 \mathrm{~m}$ at $3000 \mathrm{~m}$. The organic layer, on average containing more than $40 \% \mathrm{C}$ in the dry substance, was markedly deeper at $3000 \mathrm{~m}$ (about $0.30 \mathrm{~m}$ ) than at the lower study sites (about $0.15 \mathrm{~m})$.

The mean annual rainfall at $1900 \mathrm{~m}(1950 \mathrm{~mm})$ was lower than at $2400 \mathrm{~m}(5000 \mathrm{~mm})$ and $3000 \mathrm{~m}$ $(4500 \mathrm{~mm})$. Mean annual temperature decreased markedly from $14.9^{\circ} \mathrm{C}$ at $1900 \mathrm{~m}$ to $12.3^{\circ} \mathrm{C}$ at $2400 \mathrm{~m}$ and $8.6^{\circ} \mathrm{C}$ at $3000 \mathrm{~m}$ (Röderstein et al. 2005). 


\section{METHODS}

\section{Sampling}

Foliar nutrient concentrations at the community level were assessed by the following procedure: (1) Mixed samples were taken to address the problem that plant species may differ in growth limitation by nutrients and foliar nutrient concentrations; (2) Samples were taken separately for the life forms trees (lignified and higher than $3 \mathrm{~m}$ ), shrubs (lignified and with a height of $0.5-$ $3 \mathrm{~m}$ ) and herbs (not lignified). It should be noted that the shrub life form comprised typical shrub species as well as young trees. This means that species compositions overlapped between trees and shrubs. This classification was based on another study, where the ability for nutrient uptake was assessed separately for these life forms (Soethe et al. 2006). Species classified as herbs, however, were completely different from species classified as shrubs or trees.

In October 2004 (dry season), five locations were chosen randomly at each altitude. Ten plants per life form growing closest to each location were chosen. One to several young fully developed leaves per plant were harvested, using pruning shears for trees and shrubs. The aim was to combine similar masses of leaf material from the ten plants per location to one bulked sample. Thus, from microphyllous species (e.g. Weinmannia sp. (Cunoniaceae)) more than one leaf was harvested to compensate for the reduced weight of leaf material. From species with very large leaves (e.g. Graffenrieda emarginata (Ruiz \& Pav.) Triana (Melastomataceae)), just one piece of a leaf was harvested containing leaf material from the edge to the centre of the leaf. On the day of sampling, leaf samples were dried at $50^{\circ} \mathrm{C}$.

Soil was sampled in $20 \times 20$-m plots established at each altitude. Twenty replicate locations per plot were sampled. Samples from the organic layer were taken with help of a frame $(100 \times 100-\mathrm{mm})$. Samples were divided in the upper $0.05 \mathrm{~m}$ of the organic layer $(\mathrm{O} 1)$ and the rest of the organic layer $(\mathrm{O} 2)$. Mineral soil was sampled with a soil corer $(80 \mathrm{~mm}$ in diameter) in the depths $0.0-0.1,0.1-$ $0.3,0.3-0.5$ and $0.5-0.7 \mathrm{~m}$. At the field station of the RSF, samples were stored at $4{ }^{\circ} \mathrm{C}$ for several weeks. Four of the 20 replicates were bulked together in each case to obtain five replicate samples per soil depth for analysis. Samples were directly air dried for further storage and transport to Germany.

For the determination of mineral $\mathrm{N}\left(\mathrm{N}_{\min }\right)$, samples from mineral soil were taken by soil coring. Twelve randomly distributed replicate subsamples were taken at $1900 \mathrm{~m}$, and nine at $2400 \mathrm{~m}$ and $3000 \mathrm{~m}$, respectively. Three subsamples each were combined to one sample to obtain four replicates for the analysis at $1900 \mathrm{~m}$ and three replicates at $2400 \mathrm{~m}$ and $3000 \mathrm{~m}$. At the field station in Ecuador, fresh soil samples were stored at $4{ }^{\circ} \mathrm{C}$ for a few days and then extracted with $12.5 \mathrm{mM} \mathrm{CaCl}_{2}$ (ratio soil:solution $=1: 2$ ). Thereafter, soil extracts were frozen at $20^{\circ} \mathrm{C}$. Freezing was maintained during the transport to Germany.

\section{Chemical analyses}

Chemical analyses were performed in the laboratories of the Department of Plant Nutrition and the Institute of Crop Science at the Humboldt University of Berlin, Germany. After drying at $50^{\circ} \mathrm{C}$, leaf samples and soil samples from the organic layer were ground with a flint mill (Type MM2, Retsch-GmbH and CoKG). Concentrations of total C, N and $\mathrm{S}$ were assessed with a CNS analyser (Vario Max CNS, Elementar Analysesysteme) using sulphadiazine as a standard. As certified reference samples for plant and soil material, CRM No. 180 and CRM No. 382 from the Community Bureau of Reference (BCR) were used. For determination of total $\mathrm{P}, \mathrm{K}, \mathrm{Ca}$ and $\mathrm{Mg}$ ground samples were digested with concentrated $\mathrm{HNO}_{3}$ under pressure (Heinrichs et al. 1986). Phosphorus, K, Ca and $\mathrm{Mg}$ from the mineral horizons were extracted by the Mehlich III procedure (Mehlich 1984). The Mehlich III reagent composition was $0.2 \mathrm{M} \mathrm{CH}_{3} \mathrm{COOH}, 0.25 \mathrm{M}$ $\mathrm{NH}_{4} \mathrm{NO}_{3}, 0.015 \mathrm{M} \mathrm{NH}_{4} \mathrm{~F}, 0.013 \mathrm{M} \mathrm{HNO}_{3}$ and $0.001 \mathrm{M}$ EDTA. The extraction ratio (soil weight to extractant volume) was 1:10. Concentrations of $\mathrm{Ca}, \mathrm{K}$ and $\mathrm{Mg}$ from leaf and soil samples were measured by flame atomic absorption spectrometry (Perkin Elmer 4100, Perkin Elmer) and P concentrations were determined with a spectral photometer (Specord 200, Analytik Jena) after using the molybdenum blue procedure (Murphy \& Riley 1962). For determination of $\mathrm{N}_{\min }$ in mineral soil, nitrate concentrations in the extracts were assessed with a spectral photometer (Lambda 2S, Perkin Elmer) from the difference of the extinction at a wavelength of 210 and $275 \mathrm{~nm}$ (modified from Navone 1964). Ammonium was measured photometrically at a wavelength of $636 \mathrm{~nm}$ after using the indophenol blue procedure (Bundy \& Meisinger 1994).

\section{Assessment of growth-limiting nutrients from foliar nutrient analysis}

To address the problem that critical foliar nutrient concentrations are not known for the species growing in this forest, different approaches were followed: (1) Concentration of one specific nutrient in leaves of trees was compared with critical concentrations of other tree species from literature. (2) In order to obtain further information about the relative limitation of plant growth by $\mathrm{N}$ and $\mathrm{P}$, nutrient ratios $(\mathrm{C}: \mathrm{N}, \mathrm{C}: \mathrm{P}$ and $\mathrm{N}: \mathrm{P})$ from leaf 
Table 1. Nutrient concentrations in youngest fully developed leaves of trees, shrubs and herbs at three altitudes $(\mathrm{n}=5)$. Data shown are mean \pm standard error. Altitudes that do not share upper-case letters differ significantly at $\mathrm{P}<0.05$ by Tukey multiple comparison tests.

\begin{tabular}{|c|c|c|c|c|c|c|}
\hline \multirow[b]{2}{*}{ Altitude (m) } & \multicolumn{6}{|c|}{ Nutrient concentrations $\left(\mathrm{mg} \mathrm{g}^{-1}\right)$} \\
\hline & $\mathrm{N}$ & $\mathrm{P}$ & S & $\mathrm{K}$ & $\mathrm{Ca}$ & $\mathrm{Mg}$ \\
\hline \multicolumn{7}{|l|}{ Trees } \\
\hline 1900 & $21.7 \pm 1.3^{\mathrm{A}}$ & $2.2 \pm 0.2^{\mathrm{A}}$ & $1.9 \pm 0.1^{\mathrm{A}}$ & $10.0 \pm 1.2^{\mathrm{A}}$ & $6.2 \pm 1.7^{\mathrm{A}}$ & $3.4 \pm 0.6^{\mathrm{A}}$ \\
\hline 2400 & $13.5 \pm 1.2^{\mathrm{B}}$ & $1.2 \pm 0.1^{\mathrm{B}}$ & $1.1 \pm 0.1^{\mathrm{B}}$ & $7.0 \pm 0.4^{\mathrm{AB}}$ & $7.4 \pm 1.0^{\mathrm{A}}$ & $2.7 \pm 0.2^{\mathrm{A}}$ \\
\hline 3000 & $11.3 \pm 0.3^{\mathrm{B}}$ & $1.4 \pm 0.1^{\mathrm{B}}$ & $1.2 \pm 0.1^{\mathrm{B}}$ & $5.3 \pm 0.4^{\mathrm{B}}$ & $4.9 \pm 0.3^{\mathrm{A}}$ & $3.2 \pm 0.2^{\mathrm{A}}$ \\
\hline \multicolumn{7}{|l|}{ Shrubs } \\
\hline 1900 & $22.3 \pm 2.6^{\mathrm{A}}$ & $2.0 \pm 0.4^{\mathrm{A}}$ & $1.8 \pm 0.2^{\mathrm{A}}$ & $10.2 \pm 1.2^{\mathrm{A}}$ & $9.2 \pm 2.4^{\mathrm{A}}$ & $3.6 \pm 0.6^{\mathrm{A}}$ \\
\hline 2400 & $14.9 \pm 0.9^{\mathrm{B}}$ & $1.3 \pm 0.1^{\mathrm{A}}$ & $1.3 \pm 0.2^{\mathrm{A}}$ & $7.7 \pm 0.8^{A}$ & $9.7 \pm 1.4^{\mathrm{A}}$ & $2.8 \pm 0.3^{\mathrm{A}}$ \\
\hline 3000 & $13.4 \pm 0.7^{\mathrm{B}}$ & $1.7 \pm 0.1^{\mathrm{A}}$ & $1.2 \pm 0.1^{\mathrm{A}}$ & $9.4 \pm 0.6^{\mathrm{A}}$ & $6.4 \pm 0.9^{\mathrm{A}}$ & $3.5 \pm 0.5^{\mathrm{A}}$ \\
\hline \multicolumn{7}{|l|}{ Herbs } \\
\hline 1900 & $23.7 \pm 1.9^{\mathrm{A}}$ & $3.3 \pm 0.4^{\mathrm{A}}$ & $2.2 \pm 0.2^{\mathrm{A}}$ & $22.4 \pm 1.6^{\mathrm{A}}$ & $10.0 \pm 1.5^{\mathrm{A}}$ & $4.5 \pm 0.5^{\mathrm{A}}$ \\
\hline 2400 & $15.2 \pm 1.2^{\mathrm{B}}$ & $1.5 \pm 0.1^{\mathrm{B}}$ & $1.4 \pm 0.4^{\mathrm{B}}$ & $15.4 \pm 1.3^{\mathrm{B}}$ & $5.9 \pm 0.6^{\mathrm{AB}}$ & $2.6 \pm 0.1^{\mathrm{B}}$ \\
\hline 3000 & $12.3 \pm 0.7^{\mathrm{B}}$ & $1.5 \pm 0.1^{\mathrm{B}}$ & $1.1 \pm 0.1^{\mathrm{B}}$ & $11.8 \pm 1.4^{\mathrm{B}}$ & $5.6 \pm 0.8^{\mathrm{B}}$ & $3.5 \pm 0.4^{\mathrm{AB}}$ \\
\hline
\end{tabular}

biomass were calculated and compared with nutrient ratios in literature.

\section{Calculations and statistical analyses}

To calculate nutrient stocks in soil, average bulk densities of each soil layer were used. Significant differences of foliar nutrient concentrations, nutrient stocks in soil and $\mathrm{C}$ to nutrient ratios in soil between different altitudes were assessed by ANOVA and Tukey post hoc test.

\section{RESULTS}

\section{Nutrient concentrations in leaves}

The effect of altitude on foliar nutrient concentrations of trees varied depending on the specific nutrient (Table 1). While concentrations of $\mathrm{Ca}$ and $\mathrm{Mg}$ were not affected by altitude, the concentrations of all other nutrients were lower at 2400 and $3000 \mathrm{~m}$ than at $1900 \mathrm{~m}$. The decrease of the concentrations of N, P, S and K from $1900 \mathrm{~m}$ to higher altitudes ranged between $30 \%$ and $48 \%$.

Nutrient concentrations in leaves of shrubs and herbs were similar to those in leaves of trees with the exception of higher $\mathrm{P}$ concentrations in herbs at $1900 \mathrm{~m}$ and higher $\mathrm{K}$ concentrations in herbs at all altitudes (Table 1). The effect of altitude on foliar nutrient concentration of shrubs and herbs was similar to that on foliar nutrient concentration of trees. The concentration of N, P and $\mathrm{S}$ were markedly lower at 2400 and $3000 \mathrm{~m}$ than at $1900 \mathrm{~m}$. The concentrations of $\mathrm{K}$ decreased at higher altitudes in herbs but not in shrubs. The concentrations of $\mathrm{Ca}$ and $\mathrm{Mg}$ were significantly reduced only in herbs at $2400 \mathrm{~m}$ and $3000 \mathrm{~m}$, respectively.

\section{Nutrients in the organic layer}

There was no uniform effect of altitude on total nutrient stocks in the organic layer (Figure 1). The stocks of N, S and $\mathrm{Mg}$ were significantly affected by altitude, whereby the largest stocks were found at $3000 \mathrm{~m}$. The stocks of $\mathrm{P}$, $\mathrm{K}$ and Ca were not significantly affected by altitude.

\section{Nutrients in mineral soil}

In mineral soil, stocks of $\mathrm{N}_{\min }$ in the upper $0.7 \mathrm{~m}$ were not significantly different between altitudes (Figure 2). The proportion of $\mathrm{NO}_{3}^{-}$in total $\mathrm{N}_{\text {min }}$ stocks ranged between $24 \%$ and $84 \%$, irrespectively of soil depth and altitude. The stocks of Mehlich III-extractable P, K, Ca and Mg increased markedly with increasing altitude. This was especially pronounced in the deeper soil layers below $0.3 \mathrm{~m}$.

\section{Nutrient ratios in leaves and soil substrate}

With increasing altitude, there was a marked increase of $\mathrm{C}: \mathrm{N}$ and C:P ratios in tree leaves, resulting in significantly higher $\mathrm{C}$ to nutrient ratios at 2400 and $3000 \mathrm{~m}$ than at $1900 \mathrm{~m}$ (Table 2). Highest C:N ratios occurred at $3000 \mathrm{~m}$ and highest C:P ratios at $2400 \mathrm{~m}$. Accordingly, N:P ratios were significantly higher at $2400 \mathrm{~m}$ than at $3000 \mathrm{~m}$.

Ratios of C:N and C:P in the $\mathrm{O} 1$ and $\mathrm{O} 2$ layer increased significantly with increasing altitude (Table 2). The extent of this increase (about 50\% from 1900 to $3000 \mathrm{~m}$ ) was similar in both layers. The $\mathrm{C}$ to nutrient ratios were significantly higher in the $\mathrm{O} 1$ than in the $\mathrm{O} 2$ layer (Student's t-test, $\mathrm{P}<0.05$ ), except for $\mathrm{C}: \mathrm{N}$ ratios at $2400 \mathrm{~m}$, and C:P ratios at $3000 \mathrm{~m}$, which were not significantly different between the two layers. In both soil depths, N:P ratios did not differ significantly between altitudes, but showed a tendency to be highest at $2400 \mathrm{~m}$. 

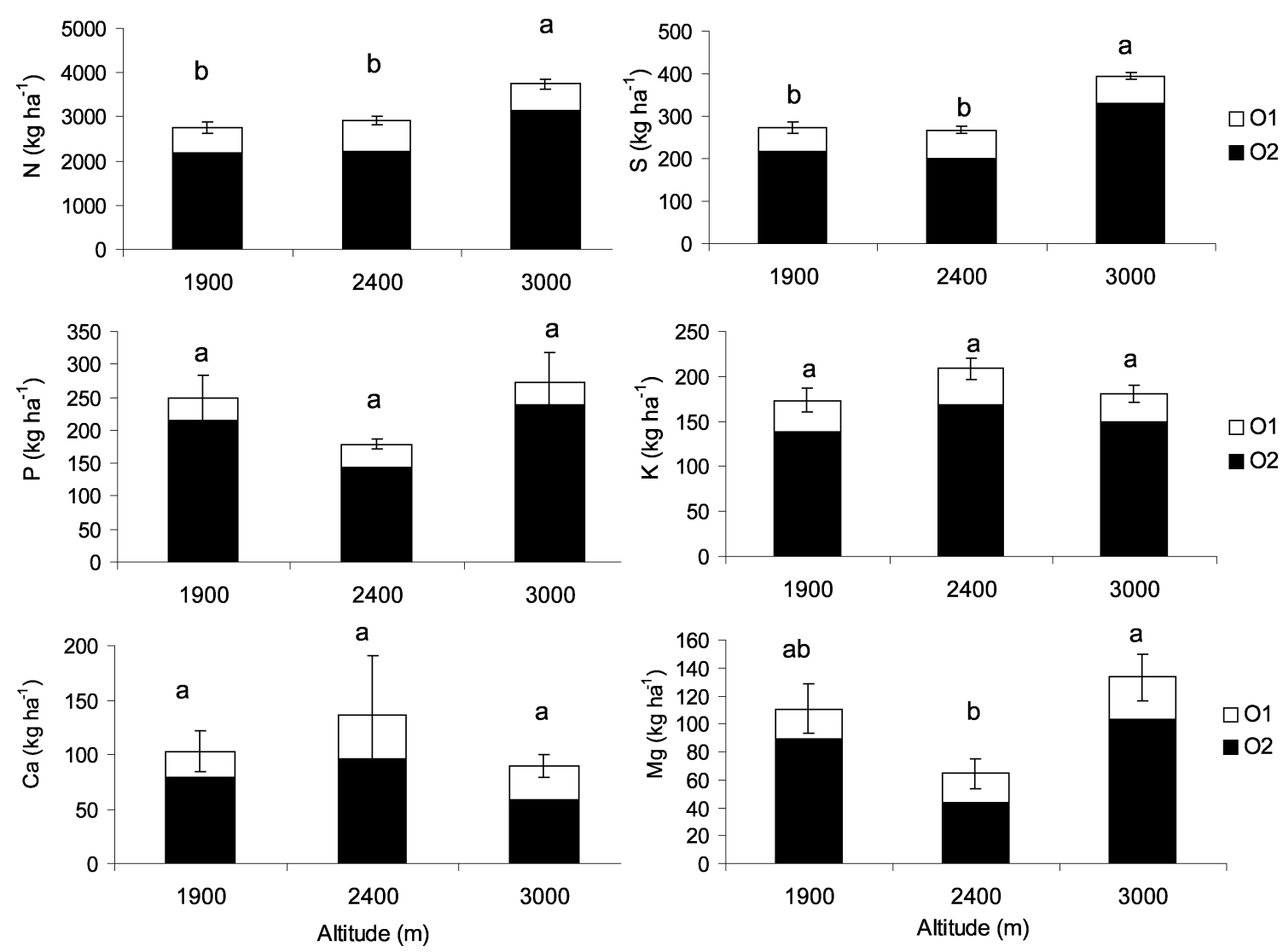

Figure 1. Total nutrient stocks in the upper $0.05 \mathrm{~m}(\mathrm{O} 1)$ and the rest $(\mathrm{O} 2)$ of the organic layer at three altitudes (mean and SE, $\mathrm{n}=5)$. Different lower-case letters indicate significant differences in nutrient stocks between altitudes (Tukey test, $\mathrm{P}<0.05$ ).

Table 2. Nutrient ratios (weight to weight) in leaves of trees and in substrate of the organic layers $(n=5)$. Data shown are mean $\pm S E$; different upper case letters show significant differences between altitudes (Tukey-test, $\mathrm{P}<0.05)$.

\begin{tabular}{lcccc}
\hline Material & $\begin{array}{c}\text { Altitude } \\
(\mathrm{m})\end{array}$ & $\mathrm{C}: \mathrm{N}$ & $\mathrm{C}: \mathrm{P}$ & $\mathrm{N}: \mathrm{P}$ \\
\hline Leaves of trees & 1900 & $23.3 \pm 1.2^{\mathrm{A}}$ & $232 \pm 21^{\mathrm{A}}$ & $10.0 \pm 0.9^{\mathrm{AB}}$ \\
& 2400 & $38.2 \pm 3.8^{\mathrm{B}}$ & $430 \pm 44^{\mathrm{B}}$ & $11.3 \pm 0.3^{\mathrm{A}}$ \\
& 3000 & $44.7 \pm 1.1^{\mathrm{B}}$ & $372 \pm 19^{\mathrm{B}}$ & $8.3 \pm 0.4^{\mathrm{B}}$ \\
Soil substrate, & 1900 & $21 \pm 1^{\mathrm{C}}$ & $351 \pm 28^{\mathrm{B}}$ & $17.2 \pm 1.6^{\mathrm{A}}$ \\
O1 layer & 2400 & $25 \pm 1^{\mathrm{B}}$ & $605 \pm 88^{\mathrm{A}}$ & $24.4 \pm 3.8^{\mathrm{A}}$ \\
& 3000 & $34 \pm 1^{\mathrm{A}}$ & $620 \pm 47^{\mathrm{A}}$ & $18.1 \pm 0.9^{\mathrm{A}}$ \\
Soil substrate, & 1900 & $19 \pm 1^{\mathrm{C}}$ & $205 \pm 32^{\mathrm{B}}$ & $10.9 \pm 1.6^{\mathrm{A}}$ \\
O2 layer & 2400 & $23 \pm 1^{\mathrm{B}}$ & $352 \pm 26^{\mathrm{AB}}$ & $15.5 \pm 0.6^{\mathrm{A}}$ \\
& 3000 & $28 \pm 1^{\mathrm{A}}$ & $432 \pm 80^{\mathrm{A}}$ & $15.1 \pm 2.7^{\mathrm{A}}$ \\
\hline
\end{tabular}

Ratios of C:N were in a similar range in leaf biomass and in soil substrate. In contrast, C:P ratios, and accordingly $\mathrm{N}: \mathrm{P}$ ratios, were markedly higher in the $\mathrm{O} 1$ layer than in leaves. C:P ratios in the $\mathrm{O} 2$ layer were similar to $\mathrm{C}: \mathrm{P}$ ratios in leaf biomass.

\section{DISCUSSION}

\section{Foliar nutrient concentrations at $1900 \mathrm{~m}$}

At $1900 \mathrm{~m}$, foliar concentrations of all macronutrients except Ca were in the ranges of nutrient sufficiency for tropical tree species (Tables 1 and 3; Bergmann 1993). Also, foliar concentrations of the micronutrients iron, copper, manganese and zinc were within the range of sufficiency given in textbooks (N. Soethe, J. Lehmann \& C. Engels, unpubl. data).

At this altitude, foliar concentrations of N, P, S, K and $\mathrm{Mg}$ were higher than the ranges of nutrient deficiency found in other studies for trees of tropical montane forests (Tanner et al. 1990, Vitousek \& Farrington 1997, Vitousek et al. 1995) and tropical lowland forests (Drechsel \& Zech 1991).

At $1900 \mathrm{~m}$, foliar C:N and C:P ratios (Table 2) were substantially lower than those reported from McGroddy et al. (2004) for temperate broad-leaved (30:1 and 357:1) and tropical lowland forests (30:1 and 951:1), supporting the suggestion that at this altitude growth was not limited by $\mathrm{N}$ or $\mathrm{P}$. This is in contrast to other tropical forest sites 


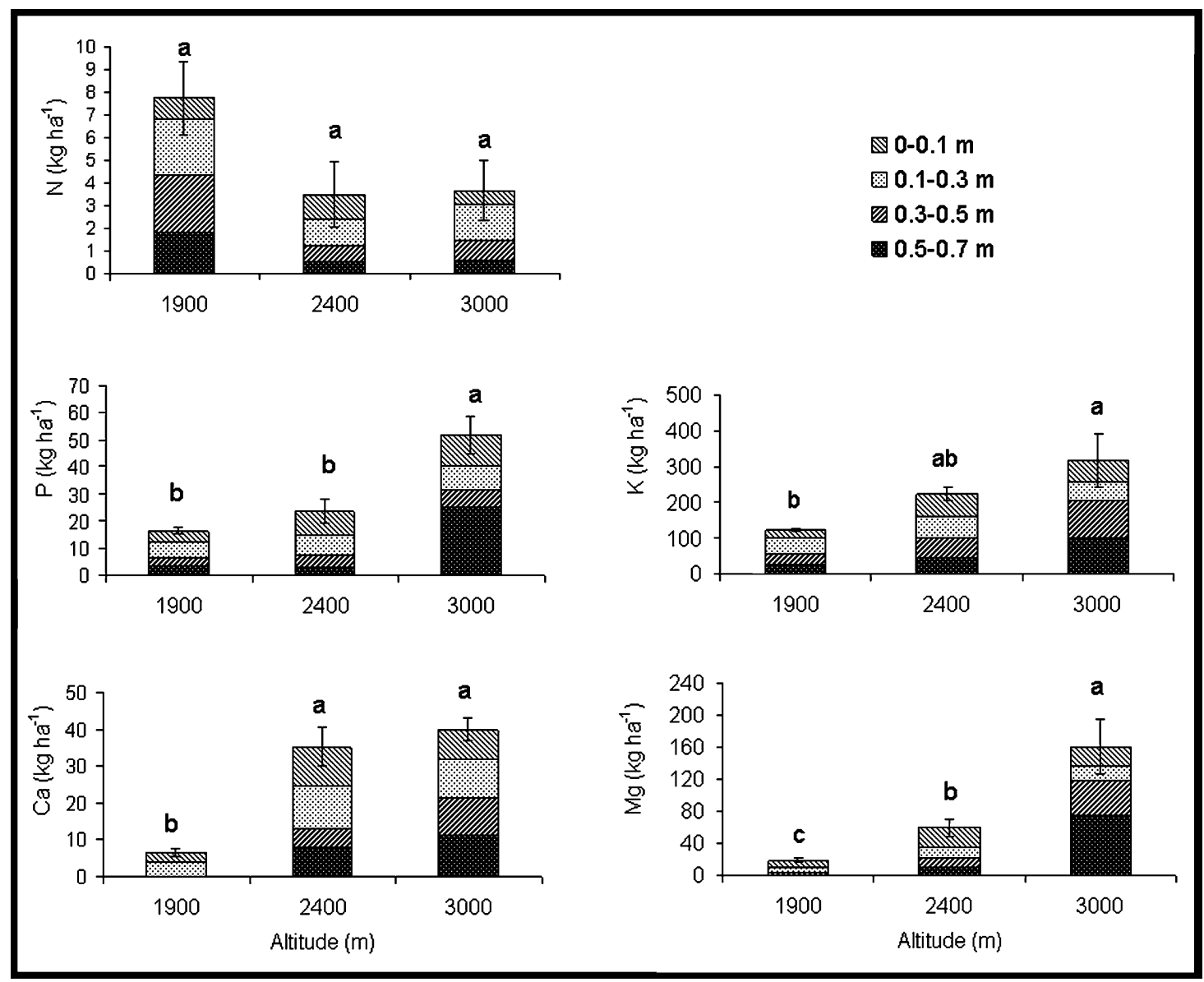

Figure 2. Stocks of $\mathrm{N}_{\min }(\mathrm{n}=3-4)$ and Mehlich III-extractable nutrients $(\mathrm{n}=5)$ in different depths of mineral soil at three altitudes (shown are mean and SE). Different lower-case letters indicate significant differences in nutrient stocks between altitudes (ANOVA, Tukey test, P < 0.05).

where growth limitation by $\mathrm{N}$ or $\mathrm{P}$ has been demonstrated (Tanner et al. 1992, Vitousek \& Farrington 1997).

In comparison to lower altitudes, however, forest growth at $1900 \mathrm{~m}$ was also reduced in the studied Ecuadorian montane forests. Since nutrient limitations are unlikely at $1900 \mathrm{~m}$ given the results shown in this study, possible causes for reduced growth in these forests include increased cloudiness (Bruijnzeel \& Veneklaas
1998 ) and direct growth reduction by low temperatures (Hoch \& Körner 2003).

Foliar $\mathrm{K}$ concentrations in herbs were about twice as high as K concentrations in lignified plants (Table 1). In temperate regions, tree species have optimal $\mathrm{K}$ concentrations between 10 and $18 \mathrm{mg} \mathrm{g}^{-1}$, whereas herbaceous species show K concentrations between 12 and $70 \mathrm{mg} \mathrm{g}^{-1}$ at optimal K supply (Bergmann 1993).

Table 3. Foliar nutrient concentrations in trees as reported from literature ( $N=$ number of tree species). ${ }^{a}$ Bergmann (1993): Ranges of foliar nutrient concentrations where neither deficiency nor toxicity occured on tropical broad-leaved tree species. ${ }^{b}$ Vitousek et al. (1995), Vitousek \& Farrington (1997): Ranges of foliar nutrient concentrations of the tree species Metrosideros polymorpha growing on sites where the respective nutrient was limiting plant growth. ${ }^{c}$ Tanner et al. (1990): Ranges of foliar nutrient concentrations of native trees with nutrient deficiency as determined by fertilization experiments. ${ }^{\mathrm{d}}$ Drechsel \& Zech (1991): Ranges of foliar nutrient concentrations where deficiency symptoms occurred at several tropical broad-leaved tree species. TMF $=$ tropical montane forest.

\begin{tabular}{|c|c|c|c|c|c|c|}
\hline \multirow[b]{2}{*}{ Location } & \multicolumn{6}{|c|}{ Nutrient concentrations $\left(\mathrm{mg} \mathrm{g}^{-1}\right)$} \\
\hline & $\mathrm{N}$ & $\mathrm{P}$ & $\mathrm{S}$ & $\mathrm{K}$ & $\mathrm{Ca}$ & $\mathrm{Mg}$ \\
\hline \multicolumn{7}{|l|}{ Nutrient sufficiency } \\
\hline Tropical zones ${ }^{\mathrm{a}}$ & $14-30(N=5)$ & $1.0-2.5(N=5)$ & $1.5-2.5(N=4)$ & $10-23(N=5)$ & $9-40(N=5)$ & $2.5-8.0(N=5)$ \\
\hline \multicolumn{7}{|l|}{ Nutrient deficiency } \\
\hline Hawaii, TMF ${ }^{b}$ & $8.7-14.2(N=1)$ & $0.6-1.0(N=1)$ & - & - & - & - \\
\hline Jamaica, $\mathrm{TMF}^{\mathrm{c}}$ & $7-18(N=4)$ & $0.5-0.6(N=1)$ & - & - & - & - \\
\hline Tropical zones ${ }^{\mathrm{d}}$ & $6-20(N=17)$ & $0.3-1.1(N=16)$ & $0.3-0.5(N=1)$ & $1.0-5.7(N=9)$ & - & $0.7-0.9(N=3)$ \\
\hline
\end{tabular}


Thus, high $\mathrm{K}$ concentrations in leaves of herbs are not necessarily related to plant nutritional status.

Foliar nutrient concentrations in shrubs showed high variation among replicates (Table 1). As a result, the effect of altitude on foliar nutrient concentrations (except for $\mathrm{N}$ ) was not significant for this life form. Possibly, variation in foliar nutrient concentrations are related to the high variation in nutrient uptake capacity from deeper soil layers by shrubs at this altitude (Soethe et al. 2006).

\section{Effect of altitude on foliar nutrient concentrations}

The effect of altitude on foliar nutrient concentrations was dependent on the specific nutrient (Table 1). While concentrations of $\mathrm{N}, \mathrm{P}, \mathrm{K}$ and $\mathrm{S}$ in trees decreased with increasing altitude, the concentrations of $\mathrm{Mg}$ and Ca were not significantly affected by altitude. This is in accordance with the studies reviewed by Tanner et al. (1998).

Foliar nutrient concentrations are usually regarded as an indicator for the nutritional status of plants (Bergmann 1993). However in mixed samples as used in our approach, differences in foliar nutrient concentrations between altitudes may also be related to differences in species composition, and may be affected by factors such as site specific characteristics of leaf morphology, adaptation to nutrient-poor soils (Chapin 1980) or dominance of species with inherently high or low nutrient concentrations (Drechsel \& Zech 1991, Tanner et al. 1990, Vitousek et al. 1995).

In Table 1, nutrient concentrations were based on leaf dry matter to allow comparisons with ranges of sufficiency or deficiency given in the literature. It has been found that in other montane forests foliar $\mathrm{N}$ and $\mathrm{P}$ concentrations decreased with increasing altitude when expressed on a leaf mass basis, whereas concentrations increased when based on leaf area (Kitayama \& Aiba 2002, Vitousek et al. 1992). Leaf morphology often changes with increasing altitude, whereby in many cases leaves become thicker and more xeromorphic. Edwards \& Grubb (1982) suggested that decreasing foliar $\mathrm{N}$ concentrations at high altitudes of tropical montane forests reflect the development of thicker cell walls, which may not be related to $\mathrm{N}$ shortage but for example aid in minimizing the infestation by fungi under cool and moist conditions. In the present study, species with xeromorphic leaves were very frequent at 2400 and $3000 \mathrm{~m}$. Nevertheless, specific leaf area (SLA) did not show the expected decrease with increasing altitude. Specific leaf area decreased significantly from $58 \mathrm{~cm}^{2} \mathrm{~g}^{-1}$ at $1900 \mathrm{~m}$ to $52 \mathrm{~cm}^{2} \mathrm{~g}^{-1}$ at $2400 \mathrm{~m}$, but was highest at $3000 \mathrm{~m}\left(61 \mathrm{~cm}^{2} \mathrm{~g}^{-1}\right)$ (Moser et al. 2007). Foliar N and P concentrations in trees decreased with increasing altitude when the concentrations were based on leaf dry matter, but also when they were based on leaf area $(\mathrm{N}: 3.1,3.0$ and $2.3 \mathrm{~g} \mathrm{~m}^{-2}$, P: $0.34,0.28$ and $0.28 \mathrm{~g} \mathrm{~m}^{-2}$ at 1900 , 2400 and $3000 \mathrm{~m}$, respectively). Thus in this study, low foliar nutrient concentrations at higher altitudes cannot be explained by leaf morphology.

The species composition at our forest sites completely changed with increasing altitude. The number of tree species was significantly higher at low than at high altitudes (Homeier 2004). Among the most frequent tree species at $3000 \mathrm{~m}$ were Weinmannia loxensis Harling (Cunoniaceae) and Clusia sp. (Clusiaceae). Possibly, nutrient concentrations in mixed leaf samples reflected foliar nutrient composition of dominant species rather than stand-specific nutrient concentrations. However, this assumption is not supported by our data where all life forms showed similar trends in the change of nutrient concentrations with increasing altitude (with the exception of significantly decreased concentrations of $\mathrm{Ca}$ and $\mathrm{Mg}$ of herbs at high altitudes; Table 1). It has to be considered that species composition in herbs completely differed from that in trees and shrubs. This indicates that the differences of foliar nutrient concentrations at different altitudes were not due to the occurrence of species with inherently low or high foliar nutrient concentrations, but result from stand-specific conditions, e.g. modification of nutrient availability.

The concentrations of N, P, S and K were substantially lower at 2400 and $3000 \mathrm{~m}$ than at $1900 \mathrm{~m}$. This shows that at higher altitudes nutrient acquisition of plants was even more affected than productivity leading to dilution of nutrients in the leaf dry matter. Furthermore, foliar concentrations of $\mathrm{N}, \mathrm{S}$ and $\mathrm{K}$ at higher altitudes decreased below the ranges of sufficiency according to reference data given by Bergmann (1993) (Table 3). Concentrations of $\mathrm{N}$ were within the ranges indicating deficiency in tropical forests. This suggests limitation of growth by deficiency of one or several nutrients at higher altitudes. It has been found that many wild plants respond to nutrient deficiency by growth reduction rather than by reduction in nutrient concentrations (Chapin 1980). This may explain the observation that foliar concentrations at 2400 and $3000 \mathrm{~m}$ were similar despite the lower growth at $3000 \mathrm{~m}$ than at $2400 \mathrm{~m}$.

\section{Possible mechanisms for the effects of altitude on plant nutritional status}

Increasing altitude may affect the plant nutritional status by modification of soil nutrient availability and the ability of plants for nutrient acquisition. In montane forests large amounts of soil nutrients are stored in the organic layer (Wilcke et al. 2002). In the present study, spatial exploitation of the organic layer by fine roots was high, ranging between 2.6 and $7.2 \mathrm{~cm}$ fine roots $\mathrm{cm}^{-3}$ soil (Soethe et al. 2006). Total amounts of nutrients in the 
organic layer were not affected by altitude for $\mathrm{P}, \mathrm{K}$ and $\mathrm{Ca}$ and were highest at $3000 \mathrm{~m}$ for N, S and Mg (Figure 1). Therefore, the decrease of leaf nutrient concentrations at high altitudes was not related to nutrient stocks in the organic layer.

In the organic layer, most $\mathrm{N}, \mathrm{P}$ and $\mathrm{S}$ are incorporated into the organic matter, and their availability is governed by the mineralization rates (Stevenson \& Cole 1999, Wilcke et al. 2002). It may be expected that mineralization of organic matter is reduced at higher altitudes because of higher $\mathrm{C}$ to nutrient ratios (Table 2), lower soil $\mathrm{pH}$, lower temperatures and less oxygen availability (McGroddy et al. 2004, Soethe et al. 2006, Wegner et al. 2003, Wilcke et al. 2002). The latter can be presumed because at $3000 \mathrm{~m}$, soils were frequently waterlogged. Therefore, plant availability of N, P and S from the organic layer may be reduced at high altitudes in spite of similar or higher total nutrient stocks in this layer (Figure 1).

Different methods were used to assess nutrient contents in mineral soil (Figure 2) and in the organic layer (Figure 1). Therefore it is not possible to draw definite conclusions on the contribution of mineral soil to plant nutrition. The amount of available $\mathrm{P}, \mathrm{K}, \mathrm{Ca}$ and $\mathrm{Mg}$ in the mineral soil, as determined by Mehlich III extraction, increased at higher altitudes (Figure 2). At the same time, root growth in mineral soil was reduced at 2400 and $3000 \mathrm{~m}$ in comparison to $1900 \mathrm{~m}$, presumably by unfavourable soil conditions such as oxygen deficiency (Soethe et al. 2006). In 0.3-0.7 m depth, where highest stocks of available $\mathrm{P}$ and $\mathrm{K}$ occurred at higher altitudes, root length density was $0.1-0.2 \mathrm{~cm} \mathrm{~cm}^{-3}$ at 2400 and $3000 \mathrm{~m}$ in comparison to $0.5-0.7 \mathrm{~cm} \mathrm{~cm}^{-3}$ at $1900 \mathrm{~m}$. That is, soil conditions may have reduced the ability of plants for nutrient acquisition from deeper soil layers. It is likely that the high amounts of plant available nutrients in mineral soil at high altitudes are related to impeded nutrient uptake in these soil layers.

\section{The extent of $\mathrm{N}$ deficiency versus $\mathrm{P}$ deficiency at high altitudes}

In leaves of trees N:P ratios varied between 8.3 and 11.3 (Table 2). These ratios are useful parameters to identify N-limited or P-limited situations (McGroddy et al. 2004, Redfield 1958, Verhoeven et al. 1996). Han et al. (2005) suggest an average $\mathrm{N}: \mathrm{P}$ ratio of $14.4: 1$ for terrestrial plant species. Tropical lowland forests are often cited as forest ecosystems that tend to be rather $\mathrm{P}$ than $\mathrm{N}$ limited (McGroddy et al. 2004, Reich \& Oleksyn 2004). Leaf biomass of these forest ecosystems show an average N:P ratio of 19.6:1 (McGroddy et al. 2004). Trees in our studies had even lower $\mathrm{N}$ :P ratios than many broad-leaved forests in temperate regions ( $\mathrm{N}: \mathrm{P}$ of 12.7:1) which tend to be more $\mathrm{N}$ limited (McGroddy et al. 2004). Thus, it is likely that $\mathrm{N}$ availability in the Ecuadorian montane forest is more critical for plant nutrition than $\mathrm{P}$ availability. It is noticeable that both, $\mathrm{N}: \mathrm{P}$ ratio and $\mathrm{C}: \mathrm{P}$ ratio, were considerably lower in leaf biomass than in the $\mathrm{O} 1$ layer that comprised relatively new leaf litter (Table 2). Low $\mathrm{P}$ concentration in the upper soil layer may result from $\mathrm{P}$ remobilization from leaves into the stem before leaf shedding, suggesting that low $\mathrm{P}$ supply from soil at high altitudes is partly compensated by efficient $\mathrm{P}$ recycling within plant biomass. This consideration is consistent with the observation of McGroddy et al. (2004) that native plant species from tropical forests have a high potential for $\mathrm{P}$ remobilization.

The significant decrease of the N:P ratio from 2400 to $3000 \mathrm{~m}$ in combination with extremely high $\mathrm{C}: \mathrm{N}$ ratios in leaf biomass at $3000 \mathrm{~m}$ leads to the conclusion that $\mathrm{N}$ availability continuously decreased from 2400 to $3000 \mathrm{~m}$. Very low $\mathrm{N}$ availability at $3000 \mathrm{~m}$ may be explained by the low abundance of $\mathrm{N}_{2}$-fixing plant species at this altitude (J. Homeier, pers. comm.). This observation supports the hypothesis of Tanner et al. (1998) that unlike tropical lowland forests, plant growth in tropical montane forests is frequently limited by $\mathrm{N}$ supply.

\section{CONCLUSIONS}

Nutrient availability markedly decreased with increasing altitude in this tropical montane forest. There is evidence that the availability of N, P, S and K was restricted at high altitudes. Low mineralization rates at these altitudes may be one important factor for the low availability of organically bound nutrients such as N, P and S. Low foliar $\mathrm{N}: \mathrm{P}$ ratios indicate that $\mathrm{N}$ supply is more critical for plant growth than $\mathrm{P}$ supply.

\section{ACKNOWLEDGEMENTS}

We are grateful to Roberth Feijoo, Virgilio Aguirre, Franz Soethe, Carmen Wolfram Wienberg and Christel Scheibe for assistance in field and laboratory. We thank INEFAN (Instituto Ecuatoriano Forestal y de Areas Naturales) for granting the research permit and the Fundacion Científica San Francisco for logistic support at the Estacíon Científica San Francisco. We gratefully acknowledge financial support supplied by the Deutsche Forschungsgemeinschaft (En342/5).

\section{LITERATURE CITED}

BARRICK, K. A. \& SCHOETTLE, A. W. 1996. A comparison of the foliar nutrient status of elfinwood and symmetrically formed tall trees, Colorado Front Range, U.S.A. Canadian Journal of Botany 74:14611475 . 
BERGMANN, W. 1993. Ernährungsstörungen bei Kulturpflanzen. Gustav Fischer Verlag, Stuttgart. 835 pp.

BRUIJNZEEL, L. A. \& VENEKLAAS, E. J. 1998. Climatic conditions and tropical montane forest productivity: the fog has not lifted yet. Ecology 79:3-9.

BRUIJNZEEL, L. A., WATERLOO, M. J., PROCTOR, J., KUITERS, A. T. \& KOTTERINK, B. 1993. Hydrological observations in montane rain forests on Gunung Silam, Sabah, Malaysia, with special reference to the "Massenerhebung" effect. Journal of Ecology 81:145-167.

BUNDY, L. G. \& MEISINGER, J. J. 1994. Nitrogen availability indices. Pp. 951-984 in Page, L. A. (ed.). Methods of soil analysis. Part 2. Microbiological and chemical properties. SSSA Book series 5. Soil Science Society of America, Madison.

CHAPIN, F. S. 1980. The mineral nutrition of wild plants. Annual Review of Ecology and Systematics 11:233-260.

CORDERO, R. A. 1999. Ecophysiology of Cecropia schreberiana saplings in two wind regimes in an elfin cloud forest: growth, gas exchange, architecture and stem biomechanics. Tree Physiology 19:153163.

DRECHSEL, P. \& ZECH, W. 1991. Foliar nutrient levels of broad-leaved tropical trees: a tabular review. Plant and Soil 131:29-46.

EDWARDS, P. J. \& GRUBB, P. J. 1977. Studies of mineral cycling in a montane rain forest in New Guinea. I. The distribution of organic matter in the vegetation and soil. Journal of Ecology 65:943969.

EDWARDS, P. J. \& GRUBB, P. J. 1982. Studies of mineral cycling in a montane rain forest in New Guinea. IV. Soil characteristics and the division of mineral elements between the vegetation and soil. Journal of Ecology 70:649-666.

FAO 1988. FAO/Unesco Soil Map of the World, Revised Legend, with corrections and updates. World Soil Resources Report 60, FAO, Rome. Reprinted with updates as Technical paper 20, ISRIC, Wageningen, 1997.

HAN, W. X., FANG, J. Y., GUO, D. L. \& ZHANG, Y. 2005. Leaf nitrogen and phosphorus stoichiometry across 753 terrestrial plant species in China. New Phytologist 168:377-385.

HEINRICHS, H., BRUMSACK, H. J., LOFTFIELD, N. \& KÖNIG, N. 1986. Verbessertes Druckaufschlusssystem für biologische und anorganische Materialien. Zeitschrift für Pflanzenernährung und Bodenkunde 149:350-353.

HERTEL, D., LEUSCHNER, C. \& HOLSCHER, D. 2003. Size and structure of fine root systems in old-growth and secondary tropical montane forests (Costa Rica). Biotropica 35:143-153.

HOCH, G. \& KÖRNER, C. 2003. The carbon charging of pines at the climatic treeline: a global comparison. Oecologia 135:10-21.

HOMEIER, J. 2004. Baumdiversität, Waldstruktur und Wachstumsdynamik zweier tropischer Bergregenwälder in Ecuador und Costa Rica. Ph.D. thesis, University of Bielefeld, Germany. 180 pp.

JUNGK, A. O. 2002. Dynamics of nutrient movement at the soil-root interface. Pp. 587-616 in Waisel, Y., Eshel, A. \& Kafkafi, U. (eds.). Plant roots, the hidden half. (Third edition). Marcel Dekker, New York.

KITAYAMA, K. \& AIBA, S. I. 2002. Ecosystem structure and productivity of tropical rain forests along altitudinal gradients with contrasting soil phosphorus pools on Mount Kinabalu, Borneo. Journal of Ecology 90:37-51.
KOTTKE, I., BECK, A., OBERWINKLER, F., HOMEIER, J. \& NEILL, D. 2004. Arbuscular endomycorrhizas are dominant in the organic soil of a neotropical montane cloud forest. Journal of Tropical Ecology 20:1-6.

LAWTON, R. O. 1982. Wind stress and elfin stature in a montane rain forest tree: an adaptive explanation. American Journal of Botany 69:1224-1230.

MCGRODDY, M. E., DAUFRESNE, T. \& HEDIN, L. O. 2004. Scaling of $\mathrm{C}: \mathrm{N}: \mathrm{P}$ stoichiometry in forests worldwide: implications of terrestrial redfield-type ratios. Ecology 85:2390-2401.

MEHLICH, A. 1984. Mehlich-3 soil test extractant: a modification of Mehlich-2 extractant. Communications in Soil Science and Plant Analysis 15:1409-1416.

MOSER, G., HERTEL, D. \& LEUSCHNER, C. 2007. Altitudinal change in LAI and stand leaf biomass in tropical montane forests: a transect study in Ecuador and a pan-tropical meta-analysis. Ecosystems 10:924-935.

MURPHY, J. \& RILEY, J. P. 1962. A modified single solution method for phosphate in natural waters. Analytica Chimica Acta 12:162-176.

NAVONE, R. 1964. Proposed method for nitrate in potable waters. Journal of the American Water Works Association 56:781-783.

REDFIELD, A. C. 1958. The biological control of chemical factors in the environment. American Scientist 46:205-221.

REICH, P. B. \& OLEKSYN, J. 2004. Global patterns of plant leaf $\mathrm{N}$ and $\mathrm{P}$ in relation to temperature and latitude. Proceedings of the National Academy of Science, USA 101:11001-11006.

RÖDERSTEIN, M., HERTEL, D. \& LEUSCHNER, D. 2005. Above- and below-ground litter production in three tropical montane forests in southern Ecuador. Journal of Tropical Ecology 21:483-492.

SCHRUMPF, M., GUGGENBERGER, G., VALAREZO, C. \& ZECH, W. 2001. Tropical montane rain forest soils. Development and nutrient status along an altitudinal gradient in the south Ecuadorian Andes. Die Erde 132:43-60.

SOETHE, N., LEHMANN, J. \& ENGELS, C. 2006. The vertical pattern of rooting and nutrient uptake at different altitudes of a south Ecuadorian montane forest. Plant and Soil 286:287-299.

STEWART, C. G. 2000. A test of nutrient limitation in two tropical montane forests using ingrowth cores. Biotropica 32:369-373.

STEVENSON, F. J. \& COLE, M. A. 1999. Cycles of soil: carbon, nitrogen, phosphorus, sulphur, and micronutrients. John Wiley and Sons, New York. 637 pp.

TANNER, E. V. J., KAPOS, V., FRESKOS, S., HEALEY, J. R. \& THEOBALD, A. M. 1990. Nitrogen and phosphorus fertilization of Jamaican montane forest trees. Journal of Tropical Ecology 6:231-238.

TANNER, E. V. J., KAPOS, V. \& FRANCO, W. 1992. Nitrogen and phosphorus fertilization effects on Venezuelan montane forest trunk growth and litterfall. Ecology 73:78-86.

TANNER, E. V. J., VITOUSEK, P. M. \& CUEVAS, E. 1998. Experimental investigation of nutrient limitation of forest growth on wet tropical mountains. Ecology 79:10-22.

TRESEDER, K. \& VITOUSEK, P. M. 2001. Effects of soil nutrient availability on investment in acquisition of $\mathrm{N}$ and $\mathrm{P}$ in Hawaiian rain forests. Ecology 82:946-954.

VANCE, E. D. \& NADKARNI, N. M. 1992. Root mass distribution in a moist tropical montane forest. Plant and Soil 142:31-39. 
VERHOEVEN, J. T. A., KOERSELMAN, W. \& MEULEMAN, A. F. M. 1996. Nitrogen- or phosphorus-limited growth in herbaceous, wet vegetation: relation with atmospheric inputs and management regimes. Trends in Ecology and Evolution 11:494-497.

VITOUSEK, P. M. \& FARRINGTON, H. 1997. Nutrient limitation and soil development: experimental test of a biogeochemical theory. Biogeochemistry 37:63-75.

VITOUSEK, P. M., APLET, G., TURNER, D. \& LOCKWOOD, J. J. 1992. The Mauna Loa environmental matrix: foliar and soil nutrients. Oecologia 89:372-382.

VITOUSEK, P. M., WALKER, L. R., WHITEAKER, L. D. \& MATSON, P. A. 1993. Nutrient limitations to plant growth during primary succession in Hawaii Volcanoes National Park. Biogeochemistry 23:197-215.
VITOUSEK, P. M., TURNER, D. R. \& KITAYAMA, K. 1995. Foliar nutrients during long-term soil development in Hawaiian montane rain forests. Ecology 76:712-720.

WEGNER, C., WUNDERLICH, M., KESSLER, M. \& SCHAWE, M. 2003. Foliar C:N ratio of ferns along an Andean elevational gradient. Biotropica 35:486-490.

WILCKE, W., YASIN, S., ABRAMOWSKI, U., VALAREZO, C. \& ZECH, W. 2002. Nutrient storage and turnover in organic layers under tropical montane rain forest in Ecuador. European Journal of Soil Science 53: $15-27$.

WILCKE, W., SCHMIDT, A., HOMEIER, J., VALAREZO, C. \& ZECH, W. (in press). Soil properties and tree growth along an altitudinal transect in Ecuadorian tropical montane forest. Journal of Plant Nutrition and Soil Science. 